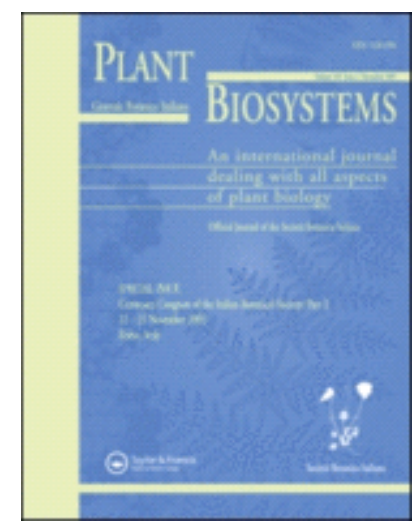

\title{
The dwarf palm tree of the king: Nannorrhops ritchiana in the 24th-23rd century BC palace of Jericho.
}

\begin{tabular}{|r|l|}
\hline Journal: & Plant Biosystems \\
\hline Manuscript ID & TPLB-2020-0023.R1 \\
\hline Manuscript Type: & Original Article \\
\hline Author: & n/a \\
\hline Complete List of Authors: & $\begin{array}{l}\text { Moricca, Claudia; Sapienza University of Rome, Department of Earth } \\
\text { Sciences; Sapienza University of Rome, Department of Environmental } \\
\text { Biology } \\
\text { Nigro, Lorenzo; Sapienza University of Rome, Department of Oriental } \\
\text { Studies } \\
\text { Gallo, Elisabetta; Sapienza University of Rome, Department of Oriental } \\
\text { Studies } \\
\text { Sadori, Laura; Sapienza University of Rome, Department of } \\
\text { Environmental Biology }\end{array}$ \\
\hline Keywords: & $\begin{array}{l}\text { Jericho, Nannorrhops ritchiana, Sacred tree, archaeobotany, } \\
\text { iconography, Early Bronze Age }\end{array}$ \\
\hline
\end{tabular}

\section{SCHOLARONE" \\ Manuscripts}




\title{
The dwarf palm tree of the king: a Nannorrhops ritchiana in the $24^{\text {th }}-23^{\text {rd }}$ century BCE palace of Jericho.
}

\author{
C. Moricca ${ }^{\text {ab }}$, L. Nigro ${ }^{c}$, E. Gallo ${ }^{\text {c }}$ L. Sadori ${ }^{\text {b }}$
}

${ }^{\text {a }}$ Department of Earth Sciences, Sapienza University of Rome, P.le Aldo Moro 5, 00185 Rome, Italy

${ }^{\mathrm{b}}$ Department of Environmental Biology, Sapienza University of Rome, P.le Aldo Moro 5, 00185 Rome, Italy

${ }^{c}$ Department of Oriental Studies, Sapienza University of Rome, Circonv.e. Tiburtina 4P.le Alde Moro 5, 00185 Rome, Italy

\begin{abstract}
Charred botanical finds from the excavation of the Early Bronze Age city of Jericho (Tell esSultan), one of the earliest urban centers of $3^{\text {rd }}$ millennium BCE Palestine, were collected during the 2015-2017 excavation seasons carried out by Sapienza University of Rome and the Palestinian MoTA-DACH. Among other plant macro-remains, a round fruit was found in the subsidiary room behind the throne room of the-Royal Palace G, next to a vase, in the burnt filling overlying the platform.

It was identified as a drupe of a dwarf palm, thanks tethrough classical archaeobotanical techniques and computed tomography scan. Two dwarf palms have beenwere taken into consideration: the Mediterranean dwarf palm (Chamaerops humilis_L.) and the Mazari palm (Nannorrhops ritchiana_(Griff.) Aitch. $\cdot \frac{\div}{2}$ native to the Saharo-Indian region), both with small, round/oval fruits, none of which currently grows in the area of Jericho. Thanks to a $\underline{A}$ detailed analysis of iconography, archaeobotanical literature and herbarium samples of both species stored in Rome (RO), Florence (FIAF) and Edinburgh (E), it was pessiblehas allowed to identify the charred drupe as Nannorrhops ritchiana. Its presence in the palace suggests the existence of
\end{abstract}


an overland commercial track to the south-east, across the desert of Saudi Arabia, which only recent excavations and other finds have revealed.

Keywords: Jericho, Nannorrhops ritchiana, Sacred Tree, archaeobotany, iconography, Early Bronze Age

\section{Introduction}

Tell es-Sultan is located in the Jericho Oasis (Fig. 1), $3 \mathrm{~km}$ from the centre of the present town of Ariha, in Palestine, at an altitude of 220 meters below sea level (Barkai and Liran 2008; Nigro $2014 a$, p. 25 28). The climate of the area is classified as arid, with hot summers and warm winters with very rare frost incidents (Mimi and Jamous 2010). The present-day vegetation has been described as a Sudano-Deccanian enclave, constituted mostly of a Ziziphus spina-christi (L.) Desf. (Christ's thorn jujube) - Balanites aegyptiaca Delile (desert date) association. Other species include Acacia tortilis (Forssk.) Hayne, Caltotropis procera Aiton and Solanum incanum

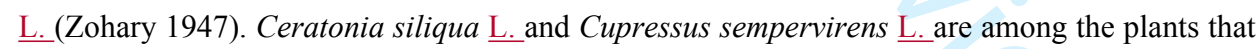
have been adapted in the area of Jericho (Ighbareyeh 2019).

[Fig. 1 near here]

The Archaeological Expedition to Jericho of the Sapienza University of Rome and the Palestinian MoTA-DACH (Ministry of Tourism and Antiquities, Department of Antiquities and Cultural Heritage) has been committed in the excavation of the Early Bronze Age city of Tell esSultan, one of the earliest urban centers of $3^{\text {rd }}$ millennium BCE (Before Common Era) Palestine (Nigro and Taha 2009; Nigro et al. 2011; 2015; Nigro 2016; Nigro 2020a). Excavations unearthed a monumental fortification system (Areas B; F, L), the northern dwelling quarter (Area F), and royal Palace $G$, the major administrative center of the city. 
A severe earthquake led to a sudden end of the life of the earliest fortified city of the Early Bronze (EB) II (Sultan IIIb Period) towards the end of the $28^{\text {th }}$ century BCE (Nigro 2014b, p. 72). The city was immediately rebuilt (2700-2500 BCE, EB IIIA, Sultan IIIc1 Period), as the life resources of the city were not swept away by the upheaval. The reconstruction of the city, thus, became an opportunity to strengthen the defensive system, with the erection of a new double city-wall with rectangular towers and blind rooms in between the outer and inner city-walls (Sellin and Watzinger 1913, p. 20-33; Garstang 1930, p. 128-129; 1931, p. 191-192; Kenyon 1981, p. 161-163, p. 210-213; Marchetti and Nigro 1998, p. 81-94, p. 129-130; Nigro 2016, p. 9 10). A major enterprise of this second urban stage was the reconstruction and enlargement of the palace on the eastern flank of the "Spring Hill" overlooking the spring and the oasis (Sellin and Watzinger 1913, p. 39-42; Garstang 1932, p. 17-18; Kenyon 1981, p. 344-346; Nigro et al. 2011, p. 586-592; Nigro 2016, p. 10-11; Nigro 2017, p. 159-162; Nigro 2020ㅁ, p. 203-204). The palace was subdivided into three wings each on a different terrace descending down to the spring. The main entrance of the palace was on its southern side and opened onto a square in the main street which climbed the Spring Hill in a northerly direction. It led to the middle terrace, where a porch opened onto a hall with a raised podium on its north side, a reception suite, flanked by a small subsidiary room (Fig. 2). Some stairs led to the upper storeys which presumably hosted the royal apartments.

[Fig. 2 near here]

The upper terrace was accessible directly from the main street, through a door in the western perimeter wall of the palace. It hosted industrial installations, with rooms for food preparation and other workshops (perhaps also a smith). A third entrance to the palace was located on the eastern lower terrace and connected directly with the spring area and the market just inside the 


\begin{abstract}
city gate. This door gave access to the administrative and storage wing of the building, and to a
\end{abstract} corner tower which possibly also served to control the access to the main street from the market area.

Several finds from the palace may illustrate multiple functions of this building. A copper axe and a dagger (with the preserved part of the handle) were found in the courtyard of the lower wing (Kenyon 1981; Nigro 2016; Nigro 2020), while a basalt potter's wheel (Dorrell 1983, p. 559560 ) and several stone tools, including grinding stones, pestles, polishing pebbles and flints were found in the upper western wing. In the central wing, big jars and pithoi belonged to the furnishings of the royal apartments (Nigro et al. 2011, p. 588; Nigro 2020).

The focus of this article is on a small subsidiary room behind the throne room of the palace, where a round stone platform was found abutting from a wall with two symmetrical high benches or niches. This installations was interpreted as a cultic one, because of the retrieval of the bull-shaped spout of a cultic vessel (Nigro et al. 2011,p. 591; Nigro 2016) The vase, possibly a kernos, was used for libation in front of a sacred image or plant, as often depicted in the art of the ancient Near East (see below).

The palace was destroyed by a fire that took place in ca. 2350 BCE (Nigro 2017, p. 164165 ; Nigro 2020, p. 205 207).

\title{
Materials and Methods
}

Botanical finds from the contexts referable to the final destruction of the city (ca. 2350/2300 BCE, EB IIIB, Sultan IIIc2 Period), were collected by hand-picking during the 2015-2017 seasons in order to be AMS radiocarbon dated (Nigro et al. 2019, p. 233 235).

Among the finds, a round seed/fruit preserved by charring was found in the subsidiary room Commented [CM1]: The mesocarp was preserved behind the throne room of the royal Palace G, next to a vase, in the burnt filling overlying the 
platform. The peculiar archaeobotanical remain was observed under a Leica M205C stereomicroscope at the Laboratory of Archaeobotany and Palynology in the Department of Environmental Biology of Sapienza University of Rome. High resolution images were acquired using the Leica IC80 HD photo camera and to the program Leica Application Suite, version 4.5.0. These were later processed using Helicon Focus, version 6.6.1 Pro, which allows to blend together shots of the same sample taken at different focus. The precise measures of the fruit's diameter were obtained using the ImageJ $1.51 \mathrm{j} 8$ software.

In order to assess the nature of the remain, a computed tomography scan was performed at the Radiology Department of the "Policlinico Umberto I" of the Sapienza University of Rome. Identification was carried out through the consultation of atlases_(Neef et al. 2012), digitized herbarium samples from the Royal Botanic Garden of Edinburgh (2018) and from the Museum Herbarium of the Sapienza University of Rome, as well as fresh samples from the Botanical Garden of the Sapienza University of Rome.

\section{Results}

The observations under the stereomicroscope allowed to describe the fruit as globose, having a smooth and uniform surface without longitudinal grooves (Fig. 3).

[Fig. 3 near here]

The specimen presents a stigma scar on its base and a pedicel scar on its apex. The measured diameter is of $12 \mathrm{~mm}$. The computed tomography scan allowed to determine the presence of one endocarp, having a different density than the rest of the fruit, leading the specimen to be classified as a drupe (Fig. 4), a fruit containing a stone seed.

[Fig. 4 near here] 
The described features closely correspond to palm fruits. While five Arecaceae genera are currently found in the Mediterranean basin and the Near and Middle East (Chamaerops, Hyphaene, Medemia, Nannorrhops and Phoenix; Dransfield et al. 2014), only the fruits of Chamaerops humilis L. (Mediterranean dwarf palm) and Nannorrhops ritchiana (Griff.) Aitch (Mazari palm or dwarf palm) seem to correspond to the description. The two species are very similar to each-other and none of them currently grows in the Levant.

The Mazari palm (Fig. 5) is a small gregarious perennial palm, with grayish green leaves, which is able to reach a height of approximately 5 meters in optimal conditions. Native to the deserts of the Saharo-Indian region, it is known as one of the most robust and versatile palms, being able to tolerate temperatures as low as $-12^{\circ} \mathrm{C}$, but also extreme heat, insufficiency of water and harsh winds (Mahmood et al. 2017; Naseem et al. 2005). N. ritchiana's fruits are described by Malik (2011 as globose or ovoid drupes of variable size in the range of 6-18 mm. Khodashenas et al. (2016) narrow the size range down to $10-13 \mathrm{~mm}$.

[Fig. 5 near here]

Chamaerops humilis, the Mediterranean dwarf palm (Fig. 6), the only palm native to Europe, closely resembles $N$. ritchiana. On average, it grows between 1 to 1.5 meters in mean height, but in protected areas it can reach a height of 10 meters (Benmehdi et al. 2012). C. humilis's underground rhizome produces shoots with palmate, sclerophyllous leaves. Like the Mazari palm, the Mediterranean fan palm is very tolerant to disturbance, being able to survive deforestation, fires, pasturing and cold temperatures (as low as $-9^{\circ} \mathrm{C}$; Bannister 2007; Herrera 1989). C. humilis fruits closely resemble the description of the charred specimen, being classified by Pignatti (1982) as subspherical and ovoid with size comprised between 1-3 cm. Herrera (1989) adds that they are dully yellow to brown when ripe and contain a single, stony seed. 
Likewise, Morales et al. (2016) describe them as globular reddish-brown drupe, oblong or ovoid, measuring $1-4 \mathrm{~cm}$.

Among the two, the analyzed remain fits more closely the description of $N$. ritchiana for the quasi-spherical shape, while size is not a discriminating feature.

Although in literature the drupes of the two species are described as being very similar, herbarium samples show otherwise. While N. ritchiana fruits (Fig. 5) are proven to be round, $C$. humilis fruits are clearly more elongated (Fig. 6). This points towards an identification of the charred remain as a Mazari palm fruit.

[Fig. 6 near here]

The identification of the archaeobotanical remain as $N$. ritchiana is also supported by digitized herbarium samples of $N$. ritchiana from the Royal Botanic Garden of Edinburgh (2018), as well as by the Digital Atlas of Economic Plants in Archaeology (Neef et al. 2012).

\section{Discussion}

Despite of both the fruits of Chamaerops humilis and Nannorrhops ritchiana roughly fitting the description, being ovoid and having a diameter of ca. $1 \mathrm{~cm}$, we are confident in identifying the specimen from Tell es-Sultan as Nannorrhops ritchiana. This is motivated by Mazari palm fruits being more round than the ones of the Mediterranean dwarf palm, as can be observed by comparing the specimen of $C$. humilis from two Italian herbaria, Herbarium Cesatianum stored at the Sapienza University of Rome Herbarium (RO; Fig. 5; Millozza and Giovi 2008) and Herbarium Universitatis Florentinae in Florence, with the digitized herbarium sample of $N$. ritchiana from the Royal Botanic Garden of Edinburg (E; Fig. 6).

The find of a drupe of dwarf palm proves to be of great interest in the site of Tell es-Sultan, as it represents the first such archaeobotanical record in the area. The peculiarity is enhanced by the 
fact that none of the dwarf species currently grows in the area of Jericho., nor has it been recorded by archaeobotanical evidence.

The present geographical distribution of Nannorrhops ritchiana is currently represented by the $\underline{\text { semi-desert areas of the Middle East (Iran, Afghanistan, Pakistan and Saudi Arabia; Kubitzki et }}$ al. 1998; Gratzfeld and Khan 2015; Fig. 7). In contrast, Chamaerops. and western Mediterranean, including both the European side (S Portugal, S and E Spain, SE France, W Italy and Malta) and African countries (Morocco, N Algeria and N Tunisia; GarciaCastano et al. 2014; Guzmán et al._2017). In contrast, N. ritchiana is currently found in the semidesert areas of the Middle East (Iran, Afghanistan, Pakistan and Saudi Arabia; Kubitzki et al. 1998; Gratzfeld and Khan 2015; Fig. 7).

[Fig. 7 near here]

Ethnobotanical and medicinal studies of the Mazari palm have attributed it many uses and properties, which may have influenced its importation to Jericho. Leaves are used for basket and rope making, the dried plant can be used as fuel, the ash as a coloring material. The principles extracted from the leaves have proven to be successful for the treatment of diarrhea and dysentery. They are also used as a purgative in veterinary practice (Marwat et al. 2011; $\underline{\text { Zabihullah et al. 2006). Inflorescences and fruits are used as food (Malik 1984). In particular, }}$ $\underline{\text { fruits are, in contrast with leaves, consumed for their laxative and purgative properties (Hussain }}$ et al. 2018). Finally, seeds are used as beads, in India they are chosen specifically for rosaries (Duthie et al. 1929; Khan and Shaukat 2006).

\section{$\underline{\text { Archaeobotanical evidence of dwarf palms }}$}

$\underline{\text { Some considerations may be done on the geographical distribution of archaeobotanical and }}$ historical attestations of Nannorrhops ritchiana and Chamaerops humilis. Most records of the 
Mazari palm are restricted to sites in Pakistan, where they are found in the form of seeds and fruits. Endocarps or fragments of endocarps were found in the $4^{\text {th }}-2^{\text {nd }}$ millennium $\mathrm{BC}$ sites of Miri Qalat and Shahi-Tump in the Kech valley (Tengberg 1999; Besenval et al. 2005). Fruits of N. ritchiana were found in samples from Period III (ca. 2700-2400 BC) in Sohr Damb, a prehistoric site in Central Balochistan, Pakistan (Neef et al. 2012). The possibility of such plant being cultivated is taken in consideration, although gathering from the wild is not excluded (Benecke and Neef 2003). Additionally, phytolith studies have allowed to identify N. ritchiana as the plant used for making a protohistoric net, preserved by charring in the site of Shahi-Tump (Baluchistan, Pakistan) after a fire partly destroyed a $4^{\text {th }}$ millennium BC building (Thomas et al. 2012). These sites are all located within a radius of less than $500 \mathrm{~km}$ from each other, but 3000 $\underline{\mathrm{km} \text { away from Madâ'in Sâlih (in Saudi Arabia), where charred stems of the Mazari palm, }}$ identified based on the anatomy of the fibrous vascular bundles, have been found in domestic $\underline{\text { contexts (Bouchaudl et al. 2011). Although more recent ( } 2^{\text {nd }} \text { century BC }-7^{\text {th }} \text { century AD) than }}$ the find from Tell es-Sultan, this advances the idea of $N$. ritchiana being exchanged through commercial routes with the Middle East since earlier on.

The archaeobotanical and historical attestations of Chamaerops humilis reflect its present distribution, being restricted to the coasts of the Western Mediterranean. Stones of the Mediterranean dwarf palm were found in the Iberian Peninsula in the Iron Age site of Huelva (Pérez-Jordà et al. 2017), in the $6^{\text {th }}$ millennium BCE site of Cova de les Cendres (Alicante) and in Morocco (Peña-Chocarro et al. 2015). Remains of the Mediterranean dwarf palm were also found in Early Neolithic sites of São Pedro de Canaferrim and Lapiás das Lameiras in Sintra, Portugal (López-Dóriga 2018). Charcoal fragments dating to the $1^{\text {st }}$ century AD were retrieved in a garden of a rich domus in the ancient Roman town of Privernum, in southern Latium (Sadori et 
al. 2010). The Mediterranean dwarf palm is also mentioned by the Roman author Pliny the Elder in his Naturalis Historia (Gleason 2019). C. humilis pollen also represents an evidence worth of notice, being found in the Mid- to Late-Holocene site of Sierra de Gàdor in Southern Spain (Carrión et al. 2003), in Holocene sediments from Gorgo Basso (Tinner et al. 2009) and of Biviere di Gela, both lakes on the southern coast of Sicily (Noti et al. 2009). The only find of the Mediterranean dwarf palm which falls outside its present distribution area is represented by ropes from the $9^{\text {th }}$ century AD Bozburun Byzantine shipwreck, Turkey, identified as being made of $C$. humilis fibers based on the diagnostic cell patterns of the epidermal tissue retrieved (Gorham and Bryant 2001). Such location is set at roughly $900 \mathrm{~km}$ from the site of Tell es$\underline{\text { Sultan. However, it should be considered that the find dates to the } 9^{\text {th }} \text { century AD, much more }}$ recent than the find from Jericho. Additionally, $C$. humilis is there found in the form of fibers used in rope making, therefore not testifying the use of its fruits or of the whole plant.

Archaeobotanical findings of $N$. ritchiana are restricted to sites in Pakistan and the Saudi Arabian Peninsula, where they are found both in the form of seeds and fruits, as well as stem fragments. Endocarps or fragments of endocarps were found in the $4^{\text {th }} 2^{\text {nd }}$ millennium BCE sites of Miri Qalat and Shahi Tump in the Kech valley (Tengberg 1999; Besenval et al. 2005). Fruits of $N$. ritchiana were found in samples from Period HI (ca. 27002400 BCE) in Sohr Damb, a prehistoric site in Central Balochistan, Pakistan (Neef et al. 2012). The possibility of stuch plant being cultivated is taken in consideration, although gathering from the wild is not excluded (Benecke and Neef 2003). Charred stems of $N$. ritchiana have been found in domestic contexts in the archaeological site of Madâ'in Sâlih (Saudi Arabia), dating from at least the $2^{\text {nd }}$ century $B C E$ until the $7^{\text {th }}$-century $A D$. These have been identified based on the anatomy of the fibrous vascular bundles (Bouchaudl et al. 2011; Fig. 7). Additionally, phytolith studies have allowed to 


\section{identify $N$. ritchiana as the plant used for making a protohistoric net, preserved by charring in the} site of Shahi-Tump (Baluchistan, Pakistan) after a fire partly destroyed a $4^{\text {th }}$-millennium BCE building (Thomas et al. 2012). Ethnobotanical and medicinal studies of the Mazari palm have attributed it many uses and properties. Leaves are used for basket and rope making, the dried plant can be used as fuel, the ash as a coloring material. The leaves have proven to be successful for the treatment of diarrhea and dysentery. They are also used as a purgative in veterinary practice (Marwat et al. 2011; Zabihullah et al. 2006). Inflorescences and fruits are used as food (Malik 1984). In particular, fruits are, in contrast with leaves, consumed for their laxative and purgative properties (Hussain et al. 2018). Finally, seeds are used as beads, in India they are chosen specifically for rosaries (Duthie et al. 1929; Khan and Shaukat 2006).

Ethnobotanical uses of $C$. humilis are more limited, focusing mostly on gardening and landscaping, serving as a decorative element or as a soil retainer (González-Benito et al. 2006). Leaves can be plaited into baskets (Peña-Chocarro et al. 2015). The palm occasionally has dietary purposes, with the fruits being eaten in Moroces, the heart (palmito) being consumed in Spain, and the young suckers being cooked in Italy (Haynes and MeLaughlin 2000). The roots are believed to be aphrodisiac (Abderrahim et al. 2013). The archaeobotanical and historicat attestations of $C$. humilis reflect its present distribution, being restricted to the coasts of the Western Mediterranean. Stones of the Mediterranean dwarf palm were found in the Iberian Peninsula in the Iron Age site of Huelva (Pérez-Jordà et al. 2017), in the $6^{\text {th }}$-millennium BCE site ef Cova de les Cendres (Alicante) and in Moroces (Peña Chocarro et al. 2015). Remains of the Mediterranean dwarf palm were also found in Early Neolithic sites of São Pedro de Canaferrim and Lapiás das Lameiras in Sintra, Portugal (López Dóriga 2018). Charceal fragments dating to the $1^{\text {st }}$ century $A D$ were retrieved in a garden of a rich domus in the ancient Roman town of 
Privernum, in southern Latium (Sadori et al. 2010). The Mediterranean dwarf palm is alse mentioned by the Roman author Pliny the Elder in his Naturalis Historia (Gleason 2019). Ropes from the $9^{\text {th }}$ century AD Bozburun Byzantine shipwreck, Turkey, were identified as being made of $C$. humilis fibers based on the diagnostic cell patterns of the epidermal tissue retrieved (Gorham and Bryant 2001).

C. humilis pollen also represents an evidence worth of notice, being found in the Mid- to LateHolocene site of Sierra de Gàdor in Southern Spain (Carrión et al. 2003), in Holocene sediments from Gorgo Basso (Tinner et al. 2009) and of Biviere di Gela, both lakes on the southern coast of Sicily (Noti et al. 2009).

[Fig. 8 near here]

Although both palm fruits roughly fit the description, we are confident in identifying the specimen from Tell es-Sultan as $N$. ritchiana. Firstly, this is motivated by Mazari palm fruits being more round than the ones of the Mediterranean dwarf palm, as can be observed by comparing the specimen of $C$. humilis from wo Italian herbaria, Herbarinm Cesatianm-mored at the Sapienza University of Rome Herbarium (RO; Fig. 5; Millozza and Giovi 2008) and Herbarium Universitatis Florentinae in Florence, with the digitized herbarium sample of $N$. ritchiana from the Royal Botanic Garden of Edinburg (E; Fig. 6).

Secondly, N. ritchiana has more ethnobotanical and medicinal uses than $C$. humilis, with the fruits of the former being also being consumed for their laxative and purgative properties. Finally, in terms of archaeobotanical attestations of the Mazari palm, the site of Madâ'in Sâlih (Saudi-Arabia), ca. $600 \mathrm{~km}$ away from Telles Sultan, falls outside of the present distribution area of $N$. ritchiana. Such find appears to be even more striking when put in contrast with the remaining archaeobotanical attestations of the palm, which are all located within a radius of less 


\begin{abstract}
than $500 \mathrm{~km}$ from each other, but $3000 \mathrm{~km}$ away from Madâ'in Sâlih. Although much more recent $\left(2^{\text {nd }}\right.$-century $B C E-7^{\text {th }}$-century $\left.A D\right)$ than the find from Tell es-Sultan, this advances the idea of $N$. ritchiana being exchanged through commercial routes with the Middle East since earlier on. When in come to C. humilis, whilst most of its archaeobotanical attestations fall within its present distribution range, the find in the Bozburun Byzantine shipwreck in Turkey also represents an outlier, set at roughly $900 \mathrm{~km}$ from the site of Tell es-Sultan. However, it should be considered that the find dates to the $9^{\text {th }}$-century $\mathrm{AD}$, much more recent than the find from Jericho. Additionally, C. humilis is there found in the form of fibers used in rope making, therefore not testifying the use of its fruits or of the whole plant.
\end{abstract}

\title{
The iconography of the sacred tree in the Near East
}

The retrieval of a palm fruit in the small room behind the throne room of the EBA palace of Jericho also proves to be of great interest from an archaeological perspective. The first depictions of palm-like objects in art date back to the $6^{\text {th }}-5^{\text {th }}$ millennia BCE, before the beginning of literacy, being engraved on bones from the sites of Neve-Yam and Hagoshrim in Northern Israel, and interpreted as the portrayal of a tree goddess (Orrelle and Horwitz 2016). More frequent iconographic representations of a sacred palm-like tree date back to as early as 3000 BCE, when Sumerians are supposed to have started date palm cultivation (Nixon 1951), and includedepictions on a bronze axe found in Byblos (Nigro 2003). Sacred plants worshipped by priests, kings and even hemi-mythic beings are known from Mesopotamian art (in glyptic of Akkadian, Old-Babylonian, Kassite, Assyrian), and there is evidence in several palaces (from Kish to Mari) of the presence of trees and plants for ornament or symbolic functions.

A development in the iconography of the sacred tree can be noticed around the mid $2^{\text {nd }}$ millennium BCE, under Tukulti Ninunta I. The motif continues to be seen until the end of the 


\begin{abstract}
first millennium, with a great degree of individual variability. Despite of this, it can be
\end{abstract} summarized as featuring a series of peculiar characteristics. These consist of "a trunk with a palmette crown standing on the stone base and surrounded by a network of horizontal or intersecting lines fringed with palmettes, pinecones, or pomegranates" (Parpola_1993, pp. 164).

Due to the absence of cuneiform sources expressly mentioning the tree species, scholars have developed several interpretations, without reaching a consensus on its iconography. There are three main interpretations: a) that it represents the "tree of life"; b) a date palm; c) a constructed cult object (Giovino 2007).

One of the most famous depictions of the tree scene is shown in carvings from the Northwest Palace of the Assyrian king Ashurnasirpal II (883-859 BCE), which has been thoroughly analysed and discussed (Porter 1993). Two winged figures are depicted, each of them holding a bucket and reaching out with an oval object toward a stylized tree-like object resembling a date palm found between them. The scene is closely related to the figure of the king. The most widely accepted interpretation is that proposed by Edward B. Tylor in 1890, who noted the resemblance of the stylized tree to a date palm and argued that the scene represented the artificial pollination of female date palms with pollen from male flower clusters (Tylor 1890, 386), an agrieulturat process essential to raising dates (Porter 2003). The practice was codified in the Laws of Hammurabi, dating ca. 1750 BCE (Janick 2005, p. 265 267) and already known from Mari wall paintings of the Palace of Zimri Lim (Parrot 1958) and a bronze axe found in Bybles (Nigre 2003, p. 22 23). The dioecious nature of palm trees, whose fruit yield can be greatly increased through artificial fertilization, has also caused them to be a common symbol of fertility. Additionally, the act of artificial pollination has also been used as a metaphor for human sexuality in ancient Near Eastern-societies, finding a parallel in many ancient myths, including 
the Sumerian sacred marriage between Inanna and Dummzi celebrated during the Sumerian Akitu Festival (Homan 2002). Although the date palm theory appears to have overpowered the other two, Giovino (2007) believes that the interpretation as a constructed cult object is much more promising. Langdon (1919), observing the Assyrian Sacred Tree (AST) against other Near Eastern examples, noticed that the image of worshippers before the AST was mirrored in their depiction in front of human-form or aniconic representations of gods, such as a spade and wedge, using the same gesture of worship in both cases.

Interestingly, the recovered charred fruit belongs to a different palm species than the one corresponding to the most widely accepted interpretation of iconography... It is possible that $N$. ritchiana, which is also dioecious, was purposely chosen due to its smaller size in comparison to Phoenix dactilifera and could have been more easily grown inside the structure of the palace, being kept as a sacred plant. However, iIt is also-possible that the adoration was not directed specifically to the date palm tree, but rather to a general tree or tree-like object, such as the $8^{\text {th }}$ century BCE "artificial tree" evidence found in Neo-Assyrian royal city of Khorsabad during mid-19th century excavations (Giovino 2007). Such evidence is constituted by large pieces of bronze sheathing embossed with the design of palm tree trunk scales or imbrications which had once been nailed to a shaft of cedar $9 \mathrm{~m}$ long and 0.5 thick, resulting in a metal encased pole. For this reason, a dwarf palm would have served as a perfect substitute. The small dimensions of Nannorrhops ritchiana made it more suitable for cultivation inside the palace or in sacred buildings. An additional prestige might have been given by the fact that the Mazari palm has medical properties and that it must have been imported from further areas. The latter fact also suggests the existence of an overland commercial track to the south-east, across the desert of Saudi Arabia, which only recent excavations and other finds have revealed. 


\section{Conclusions}

The presence of Nannorrhops- ritchiana in the area of Jericho represents a novelty as this species does not grow in the area and has not been attested there in the past. It is therefore believed that the fruit could have arrived from the desert areas of either the Southern Arabian Peninsula or the Middle East through a commercial network. The Mazari palm, and in particular its fruits, could have been traded due to its widely attested medical properties. However, the context of retrieval, the room adjacent to the throne room, along with Near Easter iconography, rather suggests a sacred use of N. ritchiana.

This helps to backdate the possible use of the dwarf palm as a religious symbol/cult object. Recent finds in the north-western Arabian oases of Qurraya and Tabukm, may antedate direct contacts between the Southern Levant and the Arabian Peninsula to the Early Bronze Age. Connections between Tayma and the Levant are demonstrated for the final stage of the period (Early Bronze Age IVB) and in the following Middle Bronze Age, and accentuated during the Late Bronze Age (LBA), when political and commercial contacts extended to Egypt, the Mediterranean, Assyria and Babylonia (Liu et al. 2015). The establishment of actual trade routes between the southern Arabian Peninsula and the Levant is dated to the LBA, involving the trade of incense and copper (Liu et al. 2015), enriched during the Early Iron Age with the trade of iron (Renzi et al. 2016). Although the cited studies refer to more recent archaeological periods, it is evident that this geographical area represented a fundamental junction point between Mesopotamia and the Eastern Mediterranean. Through the presentation of few, but significant 


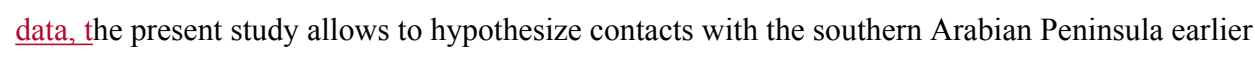
than has been previously suggested, providing a new perspective on Middle Eastern trade routes. The find of further archaeobotanical remains (charcoals, pollen, phytoliths) could help in defining whether the Mazari palm was locally grown or, as appears to be more probable, was just found at Jericho as a result of commercial exchanges. Archaeological issues at the site of Tell esSultan could help to shed some light on the issue.
\end{abstract}

\title{
Acknowledgements
}

This article is a product of the PeMSea Project [Prin2017] (A.3. Food traditions \& food plants) funded by the Italian Ministry of Scientific Research and University. The authors would like to thank the MOTA-DACH of the Palestinian National Authority for its support and constant cooperation to the research activities of Sapienza University Expedition. An acknowledgement goes to Anna Millozza and Agnese Tilia for helping in the research of dwarf palm specimens and for the digitalization of the Chamaerops humilis specimen found at the Sapienza University Herbarium of Rome, Flavio Tarquini from the Botanical Garden of the Sapienza University for providing fresh specimens of unfertilized fruits of Nannorrhops ritchiana, Lesley Scott from the Royal Botanic Garden of Edinburgh for readily providing digitized images of Nannorrhops ritchiana samples, Silvia Capuani from the Institute for Complex Systems of the National Research Council (Consiglio Nazionale delle Ricerche - CNR) and PhD candidate Sveva Longo from the Physics Department of the University of Messina for performing the CT scan and processing the images. 


\section{Bibliography}

Abderrahim O, MartinGJ, Abdelaziz A. 2013. Botanical identification and ethno-medicinal uses

of some underground part of medicinal plants collected and traded in Marrakech region. J Med Plants Res, 7(29):2165-2169.

Bannister P. 2007. Godley review: a touch of frost? Cold hardiness of plants in the southern hemisphere. New Zeal J Bot, 45(1):1-33.

Barkai R, Liran R. 2008. Midsummer sunset at Neolithic Jericho. Time and Mind, 1(3):273-283.

Benecke N, Neef R. 2003. Faunal and plant remains from Sohr Damb/Nal: a prehistoric site (c. 3500-2000 BC) in central Balochistan (Pakistan). In Franke-Vogt U, Weisshaar HJ, editors. South Asian Archaeology 2003: Proceedings of the European Association for South Asian Archaeology Conference; Jul 7-11; Bonn, Germany. Aachen: Linden Soft; p. 81-91.

Benmehdi H, Hasnaoui O, Benali O, Salhi F. 2012. Phytochemical investigation of leaves and fruits extracts of Chamaerops humilis L. J Mater Environ Sci, 3:320-337.

Besenval R, Marcon V, Buquet C, Mutin B. 2005. Shahi-Tump: Results of the Last FieldSeasons (2001-2003). S Asian Archaeol:49-56.

Bouchaud C, Thomas R, Tengberg M. 2011. The multipurpose date palm 'tree': anatomical identification of modern palm stems and practical application in the archaeological site of Madâ'in Sâlih (Saudi Arabia). Sagvntvm Extra, 11:47-48. 
Carrión JS, Sánchez-Gomez P, Mota JF, Yll R, Chaín C. 2003. Holocene vegetation dynamics, fire and grazing in the Sierra de Gádor, southern Spain. Holocene, 13(6):839-849.

Dorrell PG. 1983. Appendix A: stone vessels, tools and objects. In: Kenyon KM, Holland TA, editors. Excavations at Jericho. Vol 5. The Pottery Phases of the Tell and Other Finds. London (UK): British School of Archaeology in Jerusalem; p. 485-575.

Dransfield J, Uhl NW, Asmussen CB, Baker WJ, Hardy M, Lewis CE. 2014. Genera Palmarum: The Evolution and Classification of Palms.Chicago: University of Chicago Press.

Duthie JF, Parker RN, Turrill WB. 1929. Flora of the upper Gangetic plain, and of the adjacent Siwalik and sub-Himalayan tracts (Vol. 3, Part 3). Palmae to Cyperaceae. Calcutta: Superintendent of Government Printing.

Garcia-Castano JL, Terrab A, Ortiz MA, Stuessy TF, Talavera S. 2014. Patterns of phylogeography and vicariance of Chamaerops humilis L. (Palmae). Turk J Bot, 38(6):11321146.

Garstang J. 1930. Jericho: Sir Charles Marston’s Expedition of 1930. PEFQS 62:123-132.

Garstang J. 1931. The Walls of Jericho: The Marston-Melchett Expedition of 1931. PEFQS 63:186-196.

Garstang J. 1932. Jericho: City and Necropolis. LAAA, 19:3-22.

Giovino M. 2007. The Assyrian sacred tree: a history of interpretations (Vol. 230). Fribourg: Academic Press Fribourg.

Gleason KL. 2019. The lost dimension: pruned plants in Roman gardens. Veg Hist Archaeobot:1-15. 
González Benito ME, Huertas Micé M, Pérez García F. 2006. Seed germination and storage of Chamaerops humilis (dwarf fan palm). Seed Sci Technol, 34(1):143-150.

Gorham LD, Bryant VM. 2001. Pollen, phytoliths, and other microscopic plant remains in underwater archaeology. Int J Naut_Archaeol, 30(2):282-298.

Gratzfeld J, Khan AU. 2015. Dry Woodlands in Pakistan's Punjab Province: Piloting restoration of unique yet vanishing natural assets. Richmond: Botanic Gardens Conservation International.

Guzmán B, Fedriani JM, Delibes M, Vargas P. 2017. The colonization history of the Mediterranean dwarf palm (Chamaerops humilis L., Palmae). Tree Genet Genomes, 13(1):24.

Haynes J, MeLaughlin J. 2000. Edible palms and their uses. Gainesville (FL): University of Florida.

Herrera J. 1989. On the reproductive biology of the dwarf palm, Chamaerops humilis in southern Spain. Principes, 33(1):27-32.

Homan MM. 2002. Date rape the agricultural and astronomical background of the Sumerian sacred marriage and genesis 38, Scand J Old Testam, 16(2):283292

Hussain W, Ullah M, Dastagir G, Badshah LAL. 2018. Quantitative ethnobotanical appraisal of medicinal plants used by inhabitants of lower Kurram, Kurram agency, Pakistan. Avicenna J Phytomedicine, 8(4):313.

Ighbareyeh JMH. 2019. Bioclimate of Jericho in Palestine. Palest Tech Univ Res J, 7(1):1-7.

Janick J. 2005. The origins of fruits, fruit growing, and fruit breeding. Plant Breeding Rev, 25(1):255-320. 
Kenyon KM. 1981. Excavations at Jericho, Vol 3. The Architecture and Stratigraphy of the Tell.

London: British School of Archaeology in Jerusalem.

Khan D, Shaukat SS. 2006. The fruits of Pakistan: Diversity, Distribution, Trends of production and use. Int J Biol Biotech, 3(3):463-499.

Khodashenas M, Naanaie SY, Panahi B. 2016. Nannorrhops baluchestanica (Arecaceae), a new species from South Eastern Iran, Baluchestan Province. Iran J Bot, 22(2):101-103.

Kubitzki K, editor. 1998. The Families and Genera of Vascular Plants. Flowering Plants. Monocotyledons: Alismatanae and Commelinanae (except Gramineae). Berlin: Springer Science and Business Media.

Langdon S. 1919. XVI. Gesture in Sumerian and Babylonian Prayer. J Roy Asiatic Soc, 51(4):531-556.

Liu S, Rehren T, Pernicka E, Hausleiter A. 2015. Copper processing in the oases of northwest Arabia: technology, alloys and provenance. J Archaeol Sci, 53:492-503.

López-Dóriga IL. 2018. The archaeobotany and ethnobotany of Portuguese or white crowberry (Corema album (L.) D. Don). Ethnobio Lett, 9(2):19-32.

Mahmood A, Sharif M, Ahmad QU, Mahmood R, Riaz S, Zafar M. 2017. Phytochemical analysis and comprehensive evaluation of antimicrobial activity of Nannorhops ritchiana leaves (Mazari palm). World J Pharm Pharmaceut Sci, 6(6):173-189.

Malik KA. 2011. Nannorrhops H. Wendl. [Saint Louis (MO)]: Tropicos.org. Missouri Botanical Garden. [accessed 2019 Dec 16]. http://www.tropicos.org/Name/40025051 
Marchetti N, Nigro L. 1998. Scavi a Gerico, 1997. Relazione preliminare sulla prima campagna di scavi e prospezioni archeologiche a Tell es-Sultan, Palestina (Q Ger 1). [Excavations at Jericho, 1997. Preliminary report on the first campaign of excavations and archaeological prospecting at Tell es-Sultan, Palestine (Q Ger 1). Rome: University of Rome "La Sapienza". Italian.

Marwat SK, Usman K, Khakwani AA, Ghulam S, Anwar N, Sadiq M, Khan SJ. 2011. Medicoethnobotanical studies of edible wild fruit plants species from the flora of north western Pakistan (DI Khan district). J Med Plants Res, 5(16):3679-3686.

Miller AJ (1984). Nannorrhops ritchiana (Griff.) Aitch. E00349910 (E, Royal Botanic Garden Edinburgh). Oman. [accessed 2019 Jun 17] http://data.rbge.org.uk/herb/E00349910

Millozza A, Giovi E. 2008. L'erbario di Vincenzo Cesati a Roma [The herbarium of Vincenzo Cesati in Rome]. Museologia scientifica memorie. 2:152-155. Italian.

Mimi ZA, Jamous SA. 2010. Climate change and agricultural water demand: Impacts and adaptations. Afr J Env Sci Tech, 4(4):183-191.

Morales M, Pintó-Marijuan M, Munné-Bosch S. 2016. Seasonal, sex-and plant size-related effects on photoinhibition and photoprotection in the dioecious Mediterranean dwarf palm, Chamaerops humilis. Front Plant Sci, 7:1116.

Naseem S, Naseem S, Bashir E, Shirin K, Sheikh SA. 2005. Biogeochemical evaluation of Nannorrhops_ritchiana: A Mg-flora from Khuzdar, Balochistan, Pakistan. Chinese J Geochem, 24(4):327-337.

Neef R, Cappers RT, Bekker RM. 2012. Digital atlas of economic plants in archaeology (Vol. 17). Eelde: Barkhuis. 
Nigro L. 2003. L'ascia fenestrata e il pugnale venato: due tipologie di armi d'apparato dell'età del Bronzo Medio in Palestina. [The fenestrated ax and the veined dagger: two types of apparatus of the Middle Bronze Age in Palestine]. Bollettino dei Monumenti, Musei e Gallerie Pontificie 23:7-42. Italian.

Nigro L. 2014a. Aside the Spring: Tell es-Sultan/Ancient Jericho: the Tale of an Early City and Water Control in Ancient Palestine. In Tvedt T, Oestigaard T, editor. A History of Water. Series III. Volume 1: Water and Urbanization. London, New York. I.B. Tauris; p. 25-51.

Nigro L. 2014b. The Archaeology of Collapse and Resilience: Tell es-Sultan/ancient Jericho as a Case Study. In Nigro L, editor. Overcoming Catastrophes. Essays on disastrous agents characterization and resilience strategies in pre-classical Southern Levant (ROSAPAT 11). Rome. Rome «La Sapienza» Expedition to Palestine \& Jordan; p. 55-85.

Nigro L. 2016. Tell es-Sultan 2015: A pilot project for archaeology in Palestine. Near East Archaeol, 79(1):4-17.

Nigro L. 2017. The end of the Early Bronze Age in the Southern Levant. Urbn Crisis and Collapse seen from two $3^{\text {rd }}$ Millennium BC-Cities: Tell es-Sultan/Jericho and Khirbet alBatrawy. In Cunningham T, Driessen J, editor. Crisis to Collapse. The Archaeology of Social Breakdown (AEGIS 11). Louvain, Presses universitaires de Louvain; p. 149-172.

Nigro, L. 2020b. The Italian-Palestinian Expedition to Tell es-Sultan, Ancient Jericho (19972015): Archaeology and Valorisation of Material and Immaterial Heritage". In: Sparks RT, Finlayson B, Wagemakers B, Briffa JM, editors. Digging Up Jericho. Past, present and future. Oxford: Archaeopress Archaeology; p. 175-214. 
Nigro L. 2020a. Tell es- Sultan/Jericho in the Early Bronze Age III: Apogee of an Unusual "Palatial Society" in Palestine. In Richard S. editor. New Horizons in the Study of the Early Bronze III and Early Bronze IV of the Levant. University Park, PA. Eisenbrauns; p. 195-212.

Nigro L, Calcagnile L, Yasin J, Gallo E, Quarta G. 2019. Jericho and the Chronology of Palestine in the Early Bronze Age: A Radiometric Re-Assessment. Radiocarbon, 61(1):211-241.

Nigro L, Ripepi G, Hamdan I, Yasine J. 2015. The Jericho Oasis Archaeological Park - 2015 Interim Report. Italian-Palestinian Cooperation for protection and valorization of archaeological heritage. Vic Or, 19:219-247.

Nigro L, Sala M, Taha H, Yassine J. 2011. The Bronze Age Palace and Fortifications at Tell EsSultan/Jericho: the 6th-7th seasons (2010-2011) by Rome La Sapienza University and the Palestinian Mota-Dach. Sc Ant, 13:571-597.

Nigro L, Taha H. 2009. Renewed Excavations and Restorations at Tell es-Sultan/Ancient Jericho. Fifth Season - March-April 2009. Sc Ant, 15:733-744.

Nixon RW. 1951. The date palm - "Tree of Life" in the subtropical deserts. Econ Bot, 5(3):274-301.

Noti R, van Leeuwen JF, Colombaroli D, Vescovi E, Pasta S, La Mantia T, Tinner W. 2009. Mid-and late-Holocene vegetation and fire history at Biviere di Gela, a coastal lake in southern Sicily, Italy. Veg Hist Archaeobot, 18(5):371-387.

Orrelle E and Horwitz LK. 2016. The pre-iconography and iconology of a sixth to fifth millennium BC Near Eastern incised bone. Time and Mind, 9(1):3-42. 
Palmweb2019. Nannorrhops ritchiana (Griff.) Aitch., J. Linn. Soc., Bot. 19: 187 (1882).

Palmweb: Palms of the World Online [accessed 2019 Apr 29]

http://www.palmweb.org/cdm_dataportal/taxon/b15e6a87-761d-4ee5-ad93-

db692f8c90cf\#distribution

Parpola S. 1993. The Assyrian Tree of Life: tracing the origins of Jewish monotheism and Greek philosophy. J Near Eastern Stud, 52(3):161-208.

Parrot A. 1958. Le Palais. Peintures murales. Mission archeologique de Mari 2. Bibliotheque archeologique et historique 69. Paris: P. Geuthner.

Peña-Chocarro L, Pérez Jordà G, Morales Mateos J, Zapata, L. 2015. Storage in traditional farming communities of the western Mediterranean: Ethnographic, historical and archaeological data. Environ Archaeol, 20(4):379-389.

Pérez-Jordà G, Peña-Chocarro L, Fernández MG, Rodríguez JCV. 2017. The beginnings of fruit tree cultivation in the Iberian Peninsula: plant remains from the city of Huelva (southern Spain). Veg Hist Archaeobot, 26(5):527-538.

Pignatti S. 1982. Flora d'Italia [Italian Flora] (Vol. 3). Bologna: Edagricole. Italian.

Porter BN. 1993. Sacred Trees, Date Palms, and the Royal Persona of Ashurnasirpal II. JNear East 52(2):129 139.

Porter BN. 2003. Trees, kings, and politics: studies in Assyrian iconography. Fribourg: Academic Press Fribourg. 
Renzi M, Intilia A, Hausleiter A, Rehren T. 2016. Early Iron Age metal circulation in the Arabian Peninsula: the oasis of Tayma as part of a dynamic network [abstract]. In: Proceedings of the Seminar for Arabian Studies, 46:237-246. Archaeopress Publishing Ltd.

Sadori L, Giardini M, Susanna F. 2010. The plant landscape as inferred from a basket of the Roman town of Privernum (Latium, central Italy). Plant Biosyst, 144(4):874-887.

Sellin E, Watzinger C. 1913. Jericho: die ergebnisse der ausgrabungen [Jericho: the results of the excavations]. Leipzig: Hinrichs. German.

Tengberg M. 1999. Crop husbandry at Miri Qalat Makran, SW Pakistan (4000-2000 BC). Veg

Hist Archaeobot, 8(1-2):3-12.

Tinner W., van Leeuwen JF, Colombaroli D, Vescovi E, van der Knaap WO, Henne PD, Pasta S, D’Angelo S, La Mantia T. 2009. Holocene environmental and climatic changes at Gorgo Basso, a coastal lake in southern Sicily, Italy. Quaternary Sci Rev, 28(15-16):1498-1510.

Thomas R, Tengberg M, Moulhérat C, Marcon V, Besenval R. 2012. Analysis of a protohistoric net from Shahi Tump, Baluchistan (Pakistan). Archaeol Anthrop Sci, 4(1):15-23.

Tylor EB. 1890. The Winged Figures of the Assyrian and Other Ancient Monuments. PSBA 12:383 393.

Zabihullah Q, Rashid A, Akhtar N. 2006. Ethnobotanical survey in kot Manzaray Baba valley Malakand agency, Pakistan. Pak J Plant Sci,12(2):115-121.

Zohary, M. 1947. A vegetation map of Western Palestine. J Ecol, 1-19. 


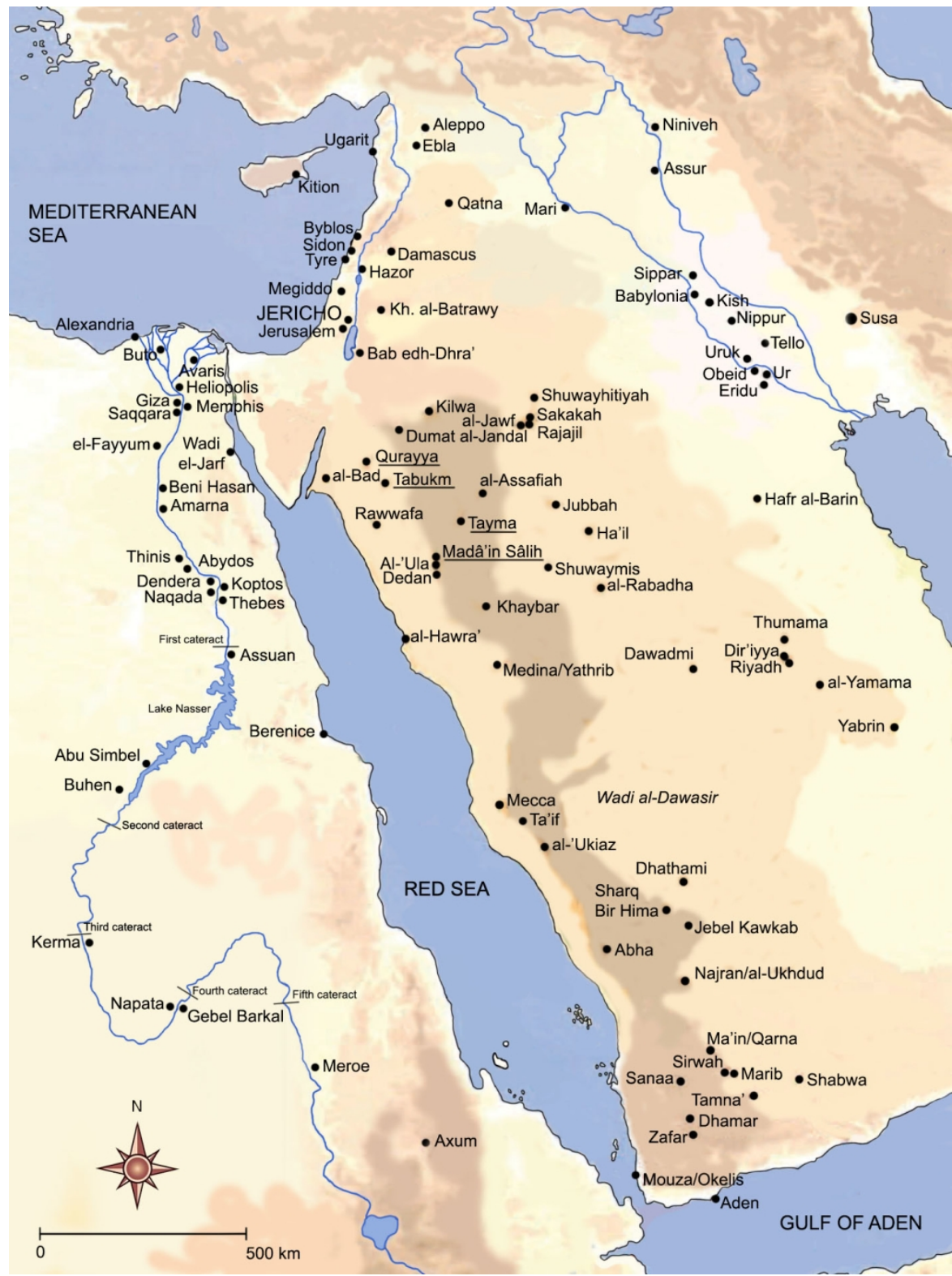

Figure 1. General map of the Near East, Egypt and Saudi Arabia Peninsula. Main archaeological sites are reported. The underlined names refer to sites quoted in the text.

$119 \times 160 \mathrm{~mm}(300 \times 300 \mathrm{DPI})$ 


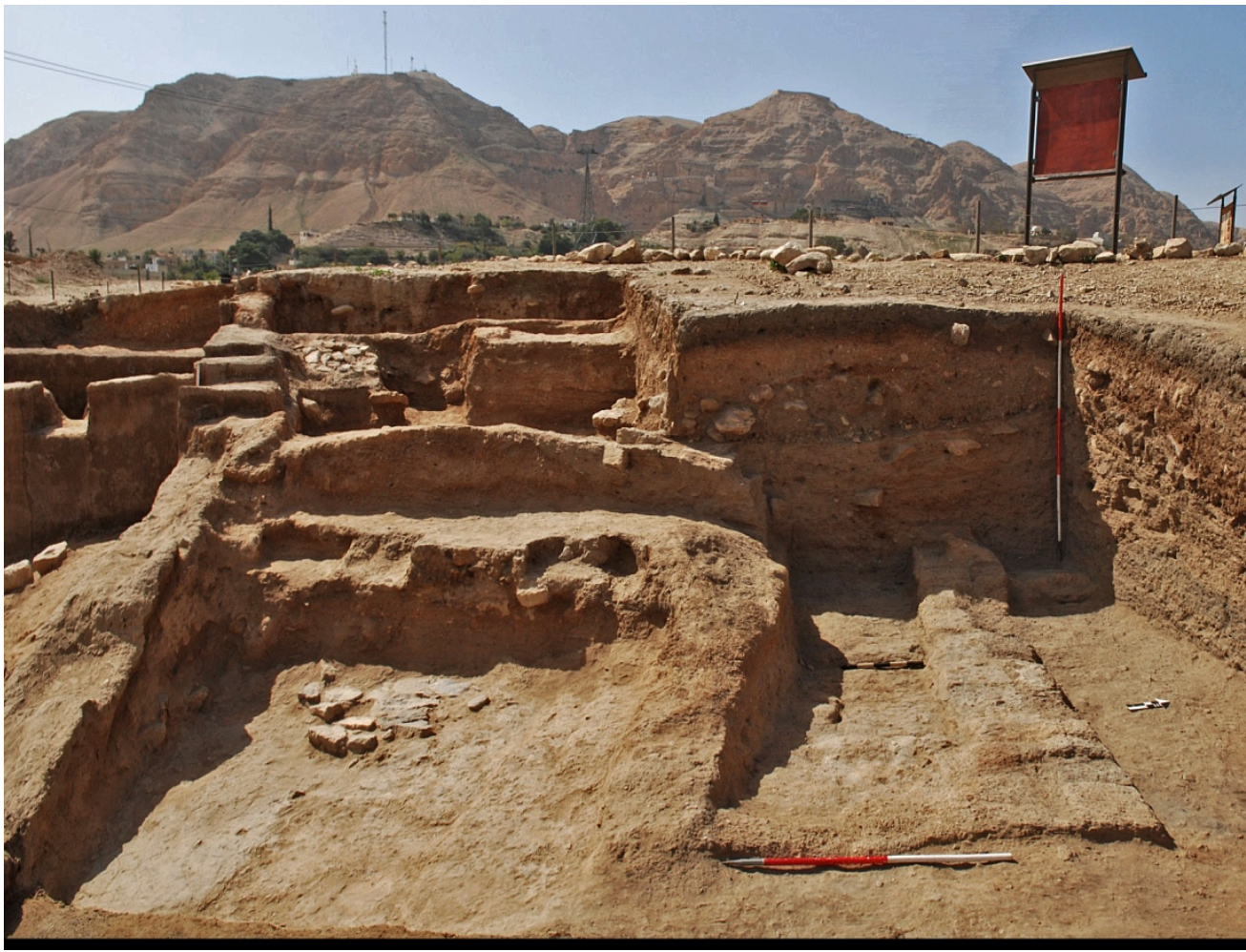

Figure 2. View of the subsidiary room L.1160 with platform L.1168 and light well L.1162 to the north brought to light in the middle terrace of EB III Palace G, from the east. (C) Sapienza University of Rome ROSEPAJ.

$612 \times 465 \mathrm{~mm}(72 \times 72 \mathrm{DPI})$ 


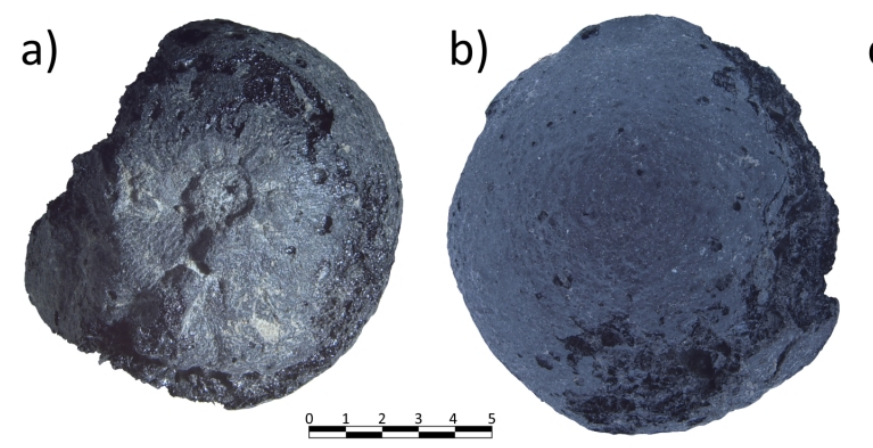

c)

Figure 3. Charred round fruit found in the archaeological site of Tell es-Sultan; a) top view, pedicel scar is visible; b) lateral view; c) bottom view, stigma scar is visible.

\section{$181 \times 65 \mathrm{~mm}(300 \times 300 \mathrm{DPI})$}


Figure 4. The investigated specimen showing the presence of only one seed inside (CT scan image). $19 \times 19 \mathrm{~mm}(300 \times 300 \mathrm{DPI})$

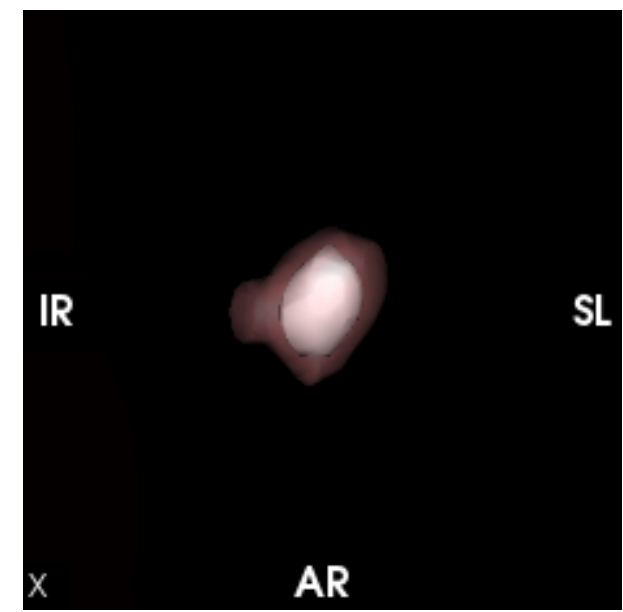




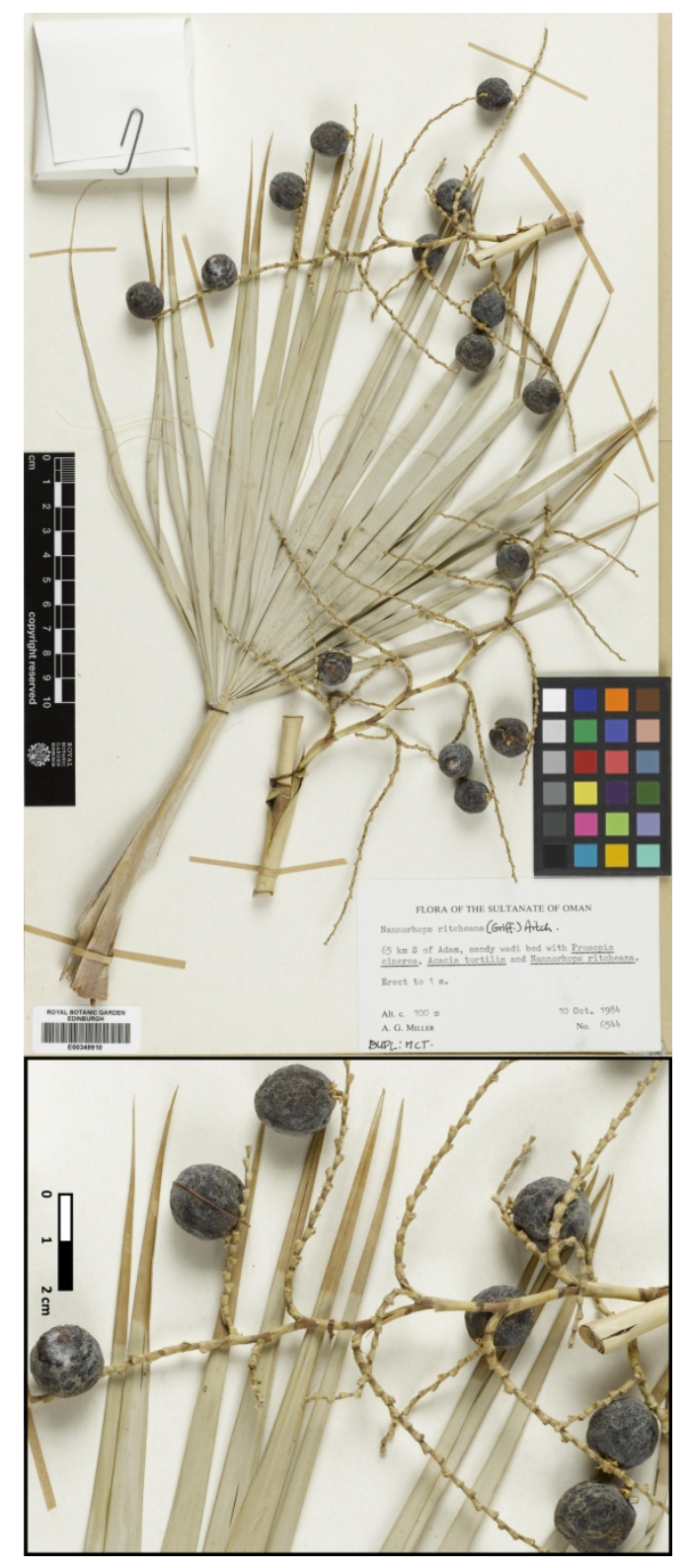

Figure 5. (a) Nannorrhops ritchiana (Griff) Aitch. specimen from the Royal Botanical Gardens of Edinburgh Herbarium (E; Miller 1984); (b) close-up of the Nannorrhops ritchiana fruits. 


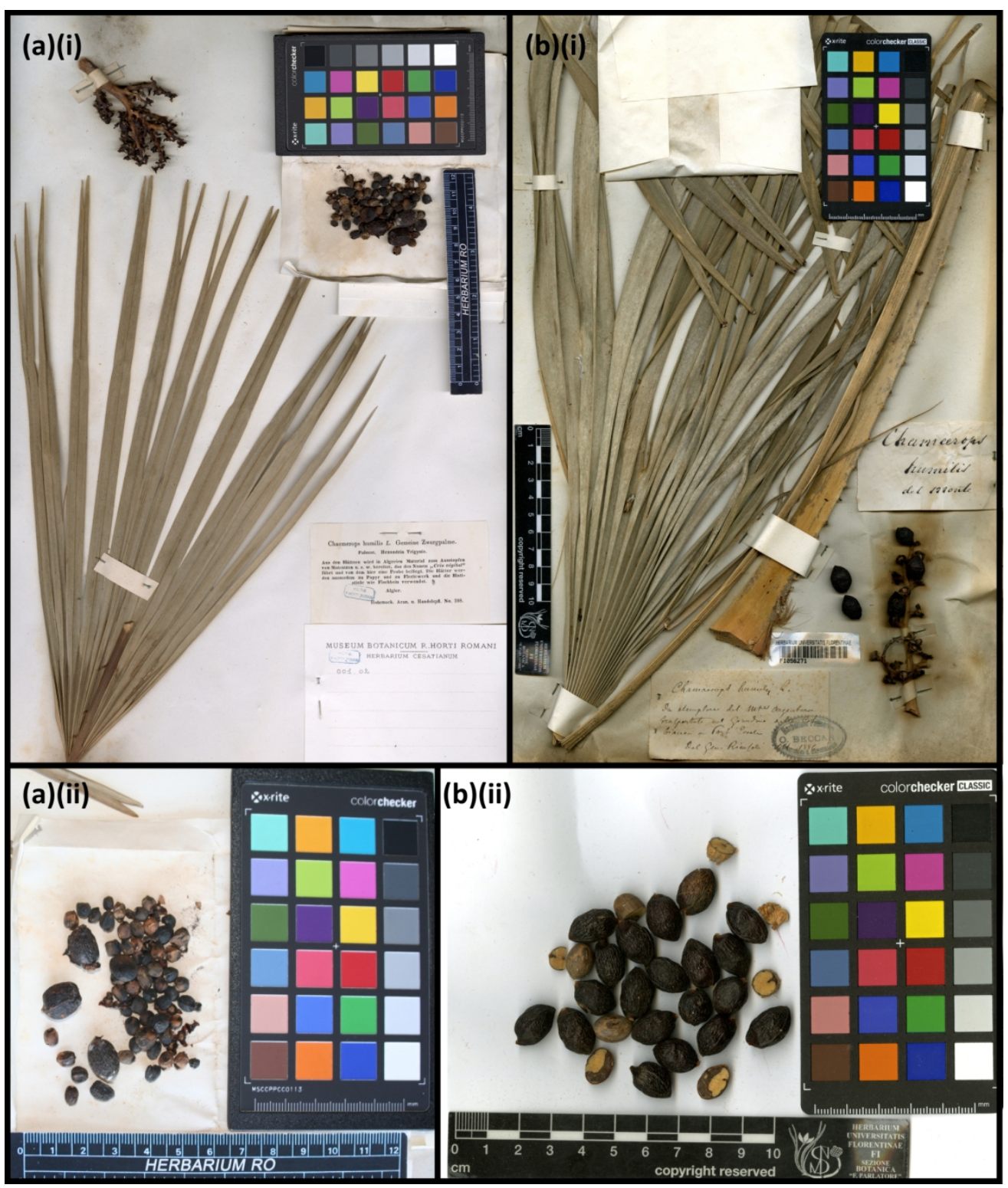

Figure 6. (a) Chamaerops humilis L. sample from the Herbarium Cesatianum held at the Museum Herbarium of the Sapienza University of Rome: (i) whole specimen, (ii) detail of the fruits; (b) Chamaerops humilis L. sample from the Herbarium Universitatis Florentinae: (i) whole specimen, (ii) detail of the fruits. $161 \times 189 \mathrm{~mm}(300 \times 300 \mathrm{DPI})$ 


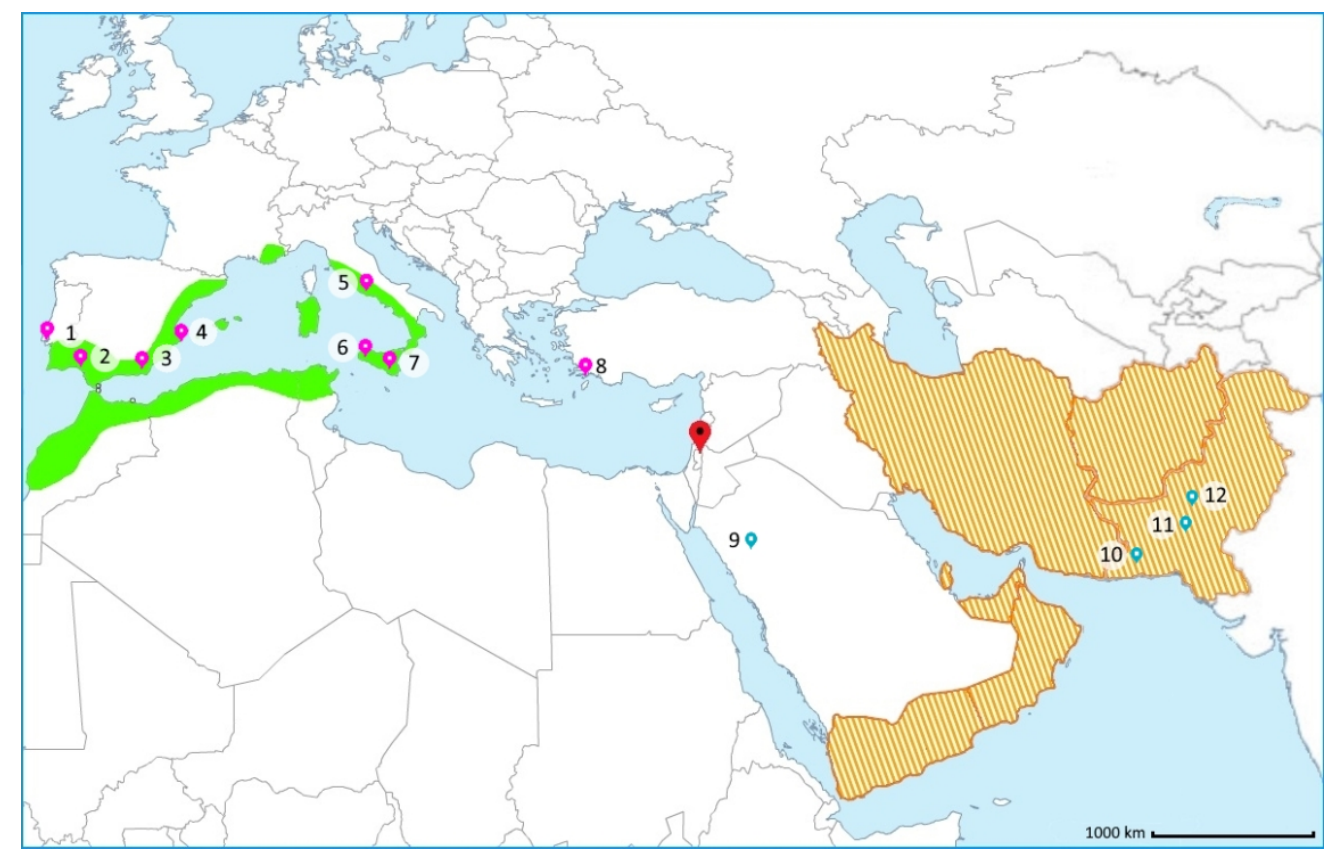

Figure 7. Present distribution map of Chamaerops humilis (green; from Garcia-Castano et al., 2014) and Nannorrhops ritchiana (striped orange; from Palmweb.org). A proper distribution map was not available for the latter, therefore whole countries where the palm is found have been highlighted. The red pin indicates the archaeological site of Tell es-Sultan (Jericho). Pink pins indicate the archaeobotanical findings of C. humilis: 1. São Pedro de Canaferrim and Lapiás das Lameiras in Sintra (charcoal); 2. Huelva (stones); 3. Sierra de Gàdor (pollen); 4. Cova de les Cendres (stones); 5. Priverno (charcoal); 6. Gorgo Basso (pollen);

7. Biviere di Gela (pollen); 8. Bozburun (fibres). Blue pins indicate the archaeological sites where N. ritchiana remains were found: 9. Madâ'in Sâlih (charcoal); 10. Shahi-Tump (endocarps, phytoliths); 11. Sohr Damb (fruits); 12. Miri Qalat (endocarps). 